\title{
Relationship between the inhibition and antioxidant properties of the plant and biomass wastes extracts - A Review
}

\author{
V.I. Vorobyova, ${ }^{1 *}$ M.I. Skiba, ${ }^{2}$ A.S. Shakun ${ }^{1}$ and S.V. Nahirniak ${ }^{1}$ \\ ${ }^{I}$ National Technical University of Ukraine "Igor Sikorsky Kyiv Polytechnic Institute”, \\ Kyiv, Ukraine. Ave Peremogy 37, Kiev, 03056, Ukraine \\ ${ }^{2}$ Ukrainian State Chemical-Engineering University, Gagarin Ave. 8, Dnipro, 49005, \\ Ukraine \\ *E-mail: vorobyovavika1988@gmail.com
}

\begin{abstract}
Corrosion inhibitors are the only most widely applied method for corrosion protection of metallic materials and are of particular importance in industry. Nowadays, the synthesis of corrosion inhibitors using traditional multistep reactions is highly restricted because of the increasing demands of "green chemistry". Plant materials and biomass wastes are ideal green candidatures to replace traditional toxic corrosion inhibitors. Literature survey reveals that different extracts of the plant and agro-food wastes contain naturally phytochemical compounds which have antioxidant properties have been effectively employing as sustainable inhibitors for the corrosion of different metals and alloys. Nevertheless, despite the numerous research papers, the reviews in which the correlation between the antioxidant/free radical scavenging activity of the extracts and their inhibition action is explained are not represented in the literature. This paper provides a brief overview of current knowledge in what kind of methods are used to estimate the antioxidant content, which classes of compounds provide higher antiradical activity and poses questions that we need to answer in order to use parameter of the antioxidant activity as a predictive index for performance evaluation of the plants/biomass wastes extracts as corrosion inhibitors. The conclusion is that no single mechanism of antioxidant actions and anticorrosive protection is operative in plant/wastes extracts. The high inhibitory efficiency is predicated on a number of complementary processes working holistically. By developing the theoretical basis and mechanism of action between the anticorrosive and antioxidant properties of plant extracts, it is possible to create predictive tools for selecting plant extract and further obtaining anti-corrosion protection based on it.
\end{abstract}

Key words: green corrosion inhibitors, antioxidant/free radical scavenging activity, phytochemicals, metals and alloys. 


\section{Introduction}

Corrosion is a phenomenon that can be frequently observed in large structures such as buildings, industrial, and transportation structures; with greater intensity in marine environments which have high salt concentrations, variations between dry and humid weather, high and low temperatures, and radiation $[1,2]$. Under these conditions, chemical and electrochemical reactions occur, resulting in the accelerated damage of the material. The damage of the material, due to exposure to certain environmental factors, results in the loss of mechanical properties. In several countries accurate studies discussing the high costs associated with corrosion have been conducted. These studies reveal that approximately $20-25 \%$ of these costs could be avoided if proper protection methods were applied [3-5]. A very recent study carried out by NACE 2016 suggests that at global level, corrosion causes economic loss of about 2.5 trillion US dollars which constitutes nearly $3.4 \%$ of total GDP. However, by implementation of existing corrosion preventing technologies in a proper way, the cost of corrosion can be reduced up to 15-35\% (375875 billion US dollars). Because of its association with very high economic and safety losses, corrosion is an important issue that has to be addressed by scientists and engineers working in the field of corrosion discipline and engineering throughout the world.

Corrosion can occur in different types of atmospheres, soils, electrolyte solutions, melted ionic environments, and environments polluted by micro-organisms [6-8].

There are various methods of protecting metals from corrosion, starting with inhibitors for various corrosive environments (contact, volatile) and ending with paint and varnish coatings and non-removable organic coatings.

Practical methods that minimize or eliminate corrosion in the chemical, mineral, fertilizer, electrons, food and beverages, energy, and manufacture industries include:

- Selection of corrosion resistant construction materials, metallic, plastic, ceramic, and composites for fabrication of the plants equipment, machinery, and structures.

- Application of paints, coating, and linings for protection of the industrial plants and energy facilities.

- Cathodic protection (CP) applying sacrificial anodic metals such as aluminium and magnesium and their alloys. An additional CP system employs impressed direct electrical current.

- Corrosion inhibition is a technique widely accepted, the vast industry of corrosion inhibitors (CI) is fast spreading worldwide for various technological and industrial applications such as petroleum oil and natural gas facilities, structures built from steel reinforced concrete, pickling and cleaning steel vehicles during production, protected transportation, and storage of electronic and military equipment; for cooling water systems; as additives for paints, coatings, elastomers, and plastics, to avoid corrosion in natural gas pipelines, to control corrosion in desalination plants [6-8]. 
To avoid the corrosion of metals, several anti-corrosive techniques are employed, but inhibition coating is the most frequently used technique. Several types of corrosion inhibitors(CI) have been developed and used for effective inhibition of metallic corrosion those can be grouped into several classes or groups. The organic compounds, inorganic metals (and their oxides)and mixtures of the inorganic-organic compounds have been successfully employed in the several common corrosive media for almost every kinds of metals and alloys. Organic compounds are most frequently utilized inhibitors among the several accessible methods of corrosion prevention. Inhibitors can be adsorbed onto the metal surface through (1) electrostatic attraction between the charged molecules of inhibitors and charged metal surface (electrostatic adsorption), (2) interaction of unshared electron pairs of the molecules with the metal surface, (3) $\pi$ bond orbital adsorption by the interaction of the presence of conjugated bonds in the inhibitors with the metal, and (4) a combination of (1) and (3). The adsorbed inhibitor film acts as a barrier between surrounding environment and metal surface thereby helps in corrosion protection [10-13]. Generally, heteroatoms of organic inhibitors exist in polar functional groups such as $-\mathrm{CN}$, $-\mathrm{NO}_{2},-\mathrm{NH}_{2},-\mathrm{OH},-\mathrm{COOH},-\mathrm{COOC}_{2} \mathrm{H}_{5},-\mathrm{OCH}_{3}$ etc. those act as adsorption centers during adsorption of these compounds on the metallic surfaces. Most of the used synthetic inhibitors are toxic for living organisms and also to the surrounding environment because of their multistep synthesis and use of conversional energy source for heating. Those are associated with huge discharge of environmental malignant chemicals into the environment and reduced yield due to their association with several workups and purification process [14-20].

Nowadays, worldwide growing ecological awareness and strict environmental protocols prevent synthesis and utilization of hazardous traditional corrosion inhibitors. In view of this, the use of traditional corrosion inhibitors is now limited because of an increasing concept of "green chemistry" in the field of science, technology, and engineering. "Green chemistry" seeks to minimize risk by minimizing the danger [20-22]. In this way, control if translated from indirect to internal factors, such as the design or selection of low toxicity chemicals and reaction pathways that exclude or ensure the quality of the by-products. Green chemistry can potentially generate even greater environmental benefits by eliminating the inherent danger of specific products or processes, thereby moving them beyond many environmental standards. It is the main component of science underlying the "responsible care" program of the chemical industry and "sustainable development". Finding some economical and environmentally friendly inhibitors is one of the major research focuses nowadays.

There has been a strong interest worldwide in developing suitable technologies that can derive chemicals and materials from renewable biomass in a number of applications, including corrosion inhibitors. Plant extracts containing heteroatoms such as $\mathrm{O}, \mathrm{N}$, and $\mathrm{S}$ have better adsorptive properties leading to better anti-corrosive behaviour [23-25]. These plant extracts are prepared from the plant materials by using different solvents and extraction methods. Consequently, organic molecules extracted from food by-products 
appear as an alternative in the field of corrosion inhibition due to their biodegradability and easy availability. In this regard, the highly effective environmental friendly corrosion inhibitors obtained from natural products such as different parts of plants like root, seeds, leaves, stem, flower, and fruits are recently attracted the high consideration of the researchers. Extensive studies of different bio-based inhibitors show that a vast number of phytochemicals can be used as efficient corrosion inhibitors [23-25].

The literature around the topic of green corrosion inhibitors for these metal surfaces is particularly active, as demonstrated in Figure 1. The number of published papers (patents included) over the topic "green corrosion inhibitors", as obtained through a SciFinder ${ }^{\circledR}$ literature review, is represented in the figure. The increase of publication shows an exponential trend.

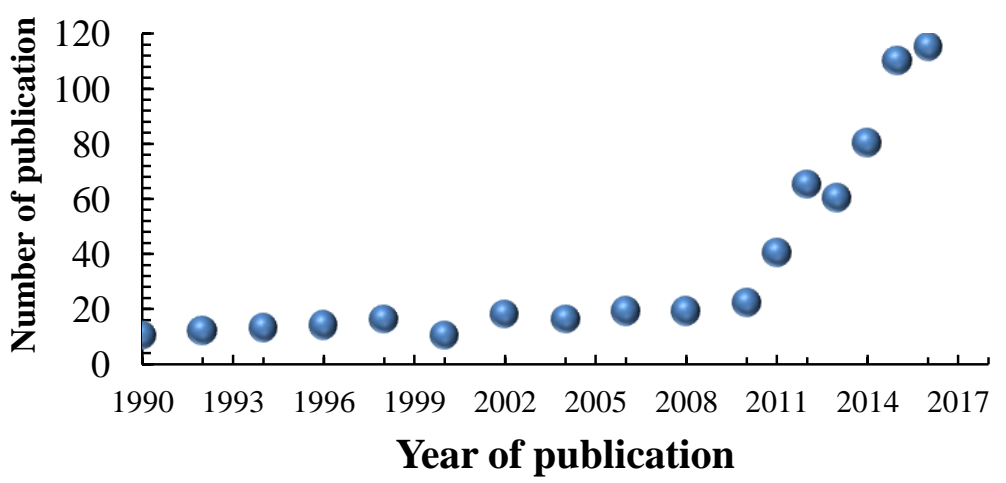

Figure 1. The interest in green inhibitors versus corrosion as indicated by number of publications. Keywords of corrosion and green inhibitors were used to retrieve the data from Web of Knowledge ${ }^{\circledR}$.

Just in the past 2018, numerous naturally occurring products such as Nettle leaves [26], Red Algae Halopitys Incurvus [27], Prosopis juliflora [28], Barley Agro-Industrial Waste [29], Matricaria recutita chamomile [30], Rollinia occidentalis[31], Glycyrrhiza glabra leaves [32], Holoptele integrifolia leaf [33], Ginkgo leaf [34], Centaurea cyanus [35], Crataegus oxyacantha and Prunus avium plant [36], Pongamia Pinnata [37], Sida Cordifolia [38], Allium sativum (garlic extract) [39], Raphanus Sativus L. [40], Borago officinalis L. [41], Cuscuta reflexa [42], Mature areca nut husk [43], Pisum sativum peels [44], grape pomace [45-47], Artemisia Judaica Herbs [48], and Opuntia Ficus-Indica [49] have been evaluated as potential corrosion inhibitors. The increase in interest in green inhibitors has stroked the eager of many researchers round the globe to search for natural plant based inhibitors.

However, the inhibitor extracted from a waste without harm to plants and environment was seldom reported. Actually, in the present ecological context, plants, food, forest or agro-industrial wastes extracts appear as an alternative to fulfil the conditions of REACH regulation and European directives on the wastewater reject [50-55]. 
The inhibition ability of the plant and agro-food wastes extracts is generally attributed to the presence of naturally phytochemical compounds which have antioxidant properties [56-58]. It has also been found that plant components (biopolymers, proteins, flavonoids, and alkaloids) exhibit effective inhibitory activity based on their antioxidant activity derived from their structure. Beside the antioxidant and free radical scavenging activity, plants extracts became also a target for the discovery of natural inhibitors of steel corrosion [59-61]. Importantly, the correlation between antioxidant/free radical scavenging activity of the extracts and the inhibition action was observed [60]. The anticorrosion and antioxidant activity of a plant extract is affected by the extraction method and the solvent used, since the extraction procedure strongly influence the composition of the extract.

However, due to the large variety of molecules contained in natural extracts, the inhibition mechanisms remain largely unknown. As for as the availability of review articles on plants extracts and they antioxidant and anticorrosive property and correlation between antioxidant/free radical scavenging activity of the extracts and they inhibition action was not found. It is important to mention that in certain cases, authors wonder about the correlation between the antioxidant and antiradical capacities of the plant extract. According to some authors the action mechanism of antioxidant and anticorrosive additive can be interpreted by terminating oxygen radical reaction and passivating film theory. The performance measurement of the antioxidantion and anticorrosive influence are reported in many literatures, but its correlation study and overviews is little relatively. The similar work published in literature has not been found up to now.

In the new publications presented in 2019 [62], the antioxidant and antiradical capacities of the water-soluble fraction (WSF) and a water-insoluble fraction (WIF) from the Pine radiata bark extracts were determined to identify which of the two is more effective as an organic corrosion inhibitor. Several authors have performed these determinations for medical applications, but never for the relationship between the antioxidant and anticorrosive capacities [63-65], which is the aim of this work.

The remaining part of this overview considers research evaluation the anti-corrosion and antioxidant properties of plant extracts and the mechanism actions the main compounds. However, what seems clear is that no single protective mechanism is operative in plants extracts and their main antioxidant compounds and that their long-term performance is predicated on a number of collaborative processes working holistically.

Analysis of the scientific and technical literature shows that the amount of research in this area is rather limited, since research topics of inhibitory and antioxidant activity belong to different fields of science and are located at the intersection of sciences. However, recently, an increasing number of publications can be used to evaluate the antioxidant activity of plant extracts, as one of the components of the primary characteristic of the prospects of using plant extract as a corrosion inhibitor. There are also publications in which the evaluation of anti-radical activity is part of a comprehensive assessment of the component composition and physicochemical properties of plant extracts 
on an equal footing with the definition of such parameters as total phenolic (TPC) and flavonoid contents (TFC).

\section{An overview of the assay methods used to estimate antioxidant content}

Various analytical methods like DPPH (1,1-diphenyl-2-picrylhydrazine), phosphomolybdenum, reducing power assay and many other tests are considered eminent in identifying the true potential of the antioxidant activity of the plant extracts. While each method has its own merits and drawbacks, it has been found that the most common and reliable methods are the ABTS and DPPH methods; these have been modified and improved in recent years $[66,67]$.

\subsection{DPPH method}

DPPH reactivity is one popular method of screening for free radical-scavenging ability in compounds, and has been used extensively for antioxidants in fruits and vegetables $[68,69]$. It is one of the most extensively used antioxidant assays for plant samples. DPPH is a stable free radical that reacts with compounds that can donate a hydrogen atom. This method is based on the scavenging of DPPH through the addition of a radical species or an antioxidant that decolorizes the DPPH solution. The antioxidant activity is then measured by the decrease in absorption at $515 \mathrm{~nm}$. In this method, a $0.1 \mathrm{mM}$ solution of DPPH in methanol is prepared, and $4 \mathrm{ml}$ of this solution is added to $1 \mathrm{ml}$ of the sample solution in methanol at varying concentrations (Figure 2).

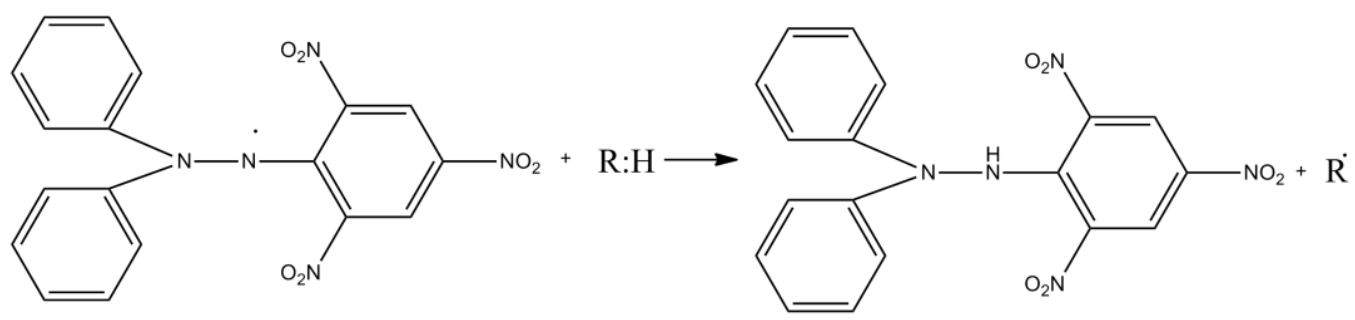

Figure 2. Reaction mechanism of 2,2-diphenyl-1-picrylhydrazyl (DPPH) with antioxidant. $\mathrm{R}: \mathrm{H}=$ antioxidant radical scavenger; $\mathrm{R} \bullet=$ antioxidant radical.

Thirty minutes later, the absorbance was measured at $517 \mathrm{~nm}$. A large decrease in the absorbance of the reaction mixture indicates significant free radical scavenging activity of the compound.

\subsection{ABTS method}

The 2,2'-azinobis(3-ethylbenzthiazoline-6-sulphonic acid), commonly called ABTS, radical scavenging method was developed by Rice-Evans and Miller and was then modified by Re et al. in 1999 [72]. The modification is based on the activation of metmyoglobin with hydrogen peroxide in the presence of $\mathrm{ABTS}^{+}$to produce a radical cation (Figure 3). 


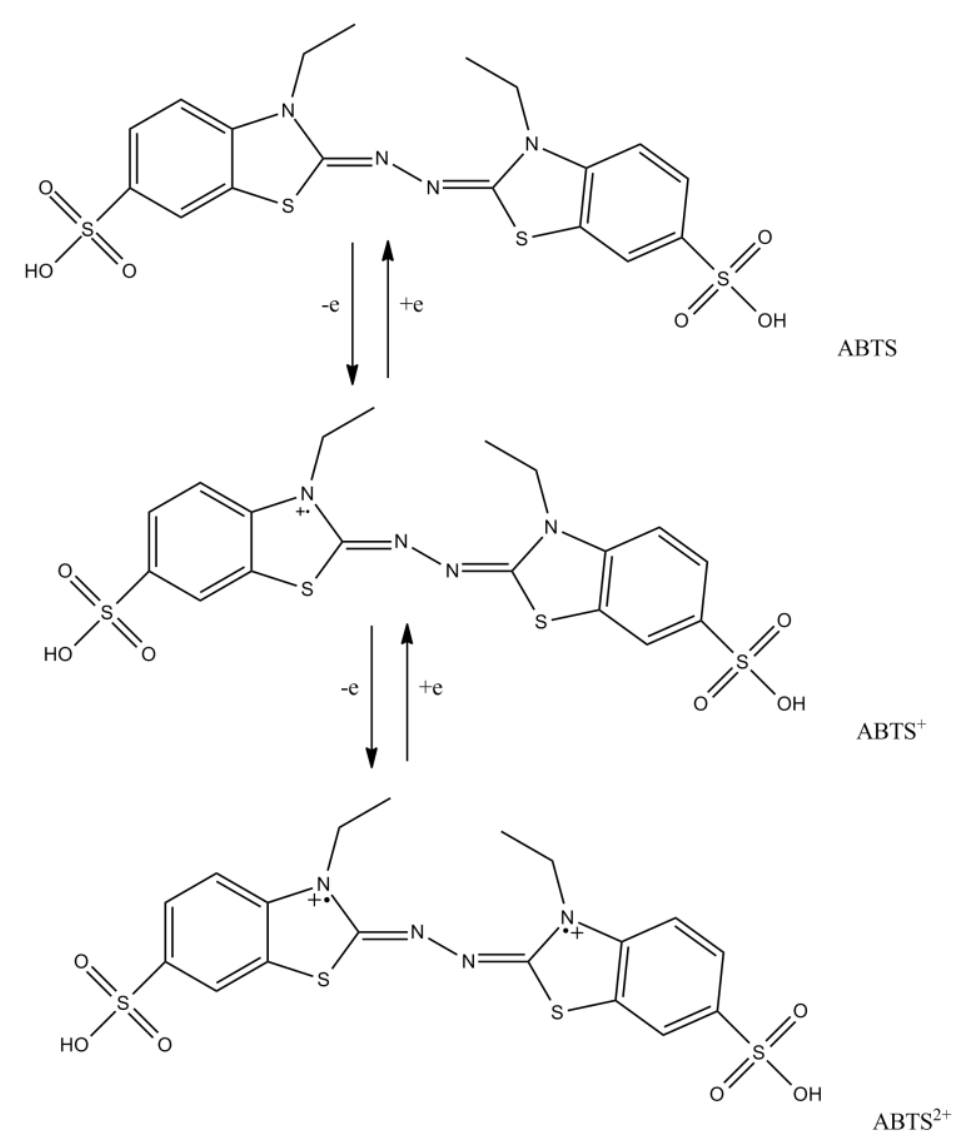

Figure 3. Reaction mechanism of 2,2'-azinobis(3-ethylbenzthiazoline-6-sulphonic acid) with antioxidant.

The improved method generates a blue/green $\mathrm{ABTS}^{+}$chromophore via the reaction of ABTS and potassium persulfate. It is now widely used. Along with the DPPH method, the ABTS radical scavenging method is one of the most extensively used antioxidant assays for plant samples. The ABTS radical cation is generated by the oxidation of ABTS with potassium persulfate, its reduction in the presence of hydrogen-donating antioxidants is measure spectrophotometrically at $734 \mathrm{~nm}$. Decolourisation assays measure the total antioxidant capacity in both lipophilic and hydrophilic substances. The effects of oxidant concentration and inhibition duration, of the radical cation's absorption are taken into account when the antioxidant activity is determined. Trolox is used as a positive control. The activity is expressed in terms of Trolox-equivalent antioxidant capacity for the extract or substance (TEAC/mg).

\subsection{Reducing power assay}

The reducing power of the samples is determined according to the method described by Oyaizu [67-73]. The sample in $1 \mathrm{ml}$ of methanol is mixed with a phosphate buffer $(5 \mathrm{ml}$, $0.2 \mathrm{M}, \mathrm{pH}$ 6.6) and potassium ferricyanide $(5 \mathrm{ml}, 1 \%)$, and the mixture is incubated at $50^{\circ} \mathrm{C}$ for $20 \mathrm{~min}$. Next, $5 \mathrm{ml}$ of trichloroacetic acid (10\%) is added to the reaction mixture, which is then centrifuged at $3000 \mathrm{RPM}$ for $10 \mathrm{~min}$. The upper layer of the solution $(5 \mathrm{ml})$ 
is mixed with distilled water $(5 \mathrm{ml})$ and ferric chloride $(1 \mathrm{ml}, 1 \%)$, and the absorbance is measured at $700 \mathrm{~nm}$. A stronger absorbance indicates increased reducing power.

The uses of an indicator of antioxidant activity as an indirect assessment of the inhibitory effect would save significant time in the process of developing corrosion inhibitors based on plant material sand importantly allow a greater proportion of the different types of plant material to be explored systematically. Key to achieving this goal is a greater understanding of the mechanisms of antioxidant/free radical scavenging activity of the extracts and the inhibition action the extract and, critically, how the individual components of the extract system act in concert to achieve the overall protective effectiveness.

\subsection{Chelating effect on ferrous ions}

Chelating activity of samples can be determined by the ferrozine assay. Ferrozine quantitatively forms complexes with $\mathrm{Fe}^{2+}$. In the presence of other chelating agents, thecomplex formation is disrupted with a resulting decrease in the red colour of the complex. Measurement of the rate of colour reduction allows estimation of the chelating activity of the coexistent chelator.

\subsection{Ferric-reducing antioxidant power (FRAP) assay}

In order to assess the modifying effect of tea flavonoids on plasma antioxidant status, a variety of methods has been employed. Commonly used is the FRAP assay. This is a colorimetric assay that measures the ability of plasma to reduce the intense blue ferric tripyridyltriazine complex (TPTZ) to its ferrous form, thereby changing its absorbance.

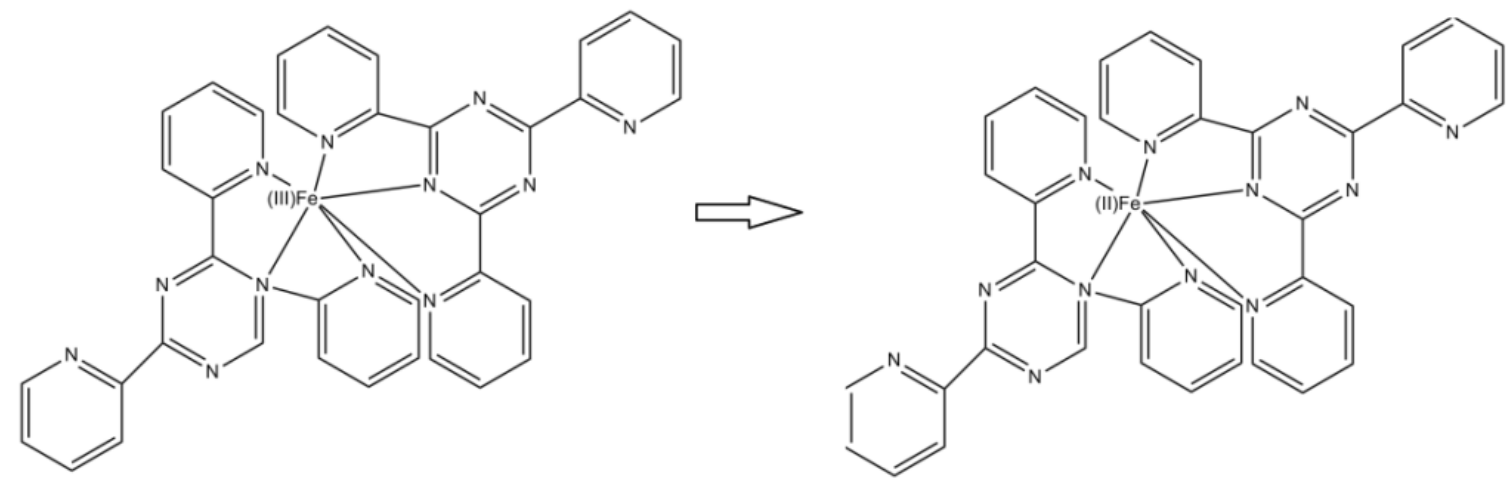

Figure 4. Reaction for FRAP assay $\left(\mathrm{Fe}^{3+}-\mathrm{TPTZ}+\right.$ reducing antioxidant $\left(\mathrm{Fe}^{2+}-\mathrm{TPTZ} \longrightarrow\right.$ intense blue at $595 \mathrm{~nm}$ ).

1.6. Determination of the anticorrosion and antioxidant properties plant extracts that contained polyphenolic compounds

A literature review has shown that most of the work is devoted to assessing the inhibitory and antioxidant properties of extracts in acidic corrosive environments. As well as for the most part, the antioxidant properties of the most significant class of compounds, 
polyphenolic compounds, are considered (Figure 5). In nature, especially in plants, they are frequently found as glycosides, in order to ensure their water solubility and favour their absorption by the organisms. According to many authors the corrosion inhibition ability of plant extracts is generally attributed to the presence of secondary metabolites containing antioxidant polyphenolic compounds constituents like alkaloids, flavonoids, or condensed tannins (Figure 5). Natural polyphenols are non-polymeric compounds containing benzene rings substituted with several hydroxyl groups that demonstrate good adhesive and antioxidant properties.

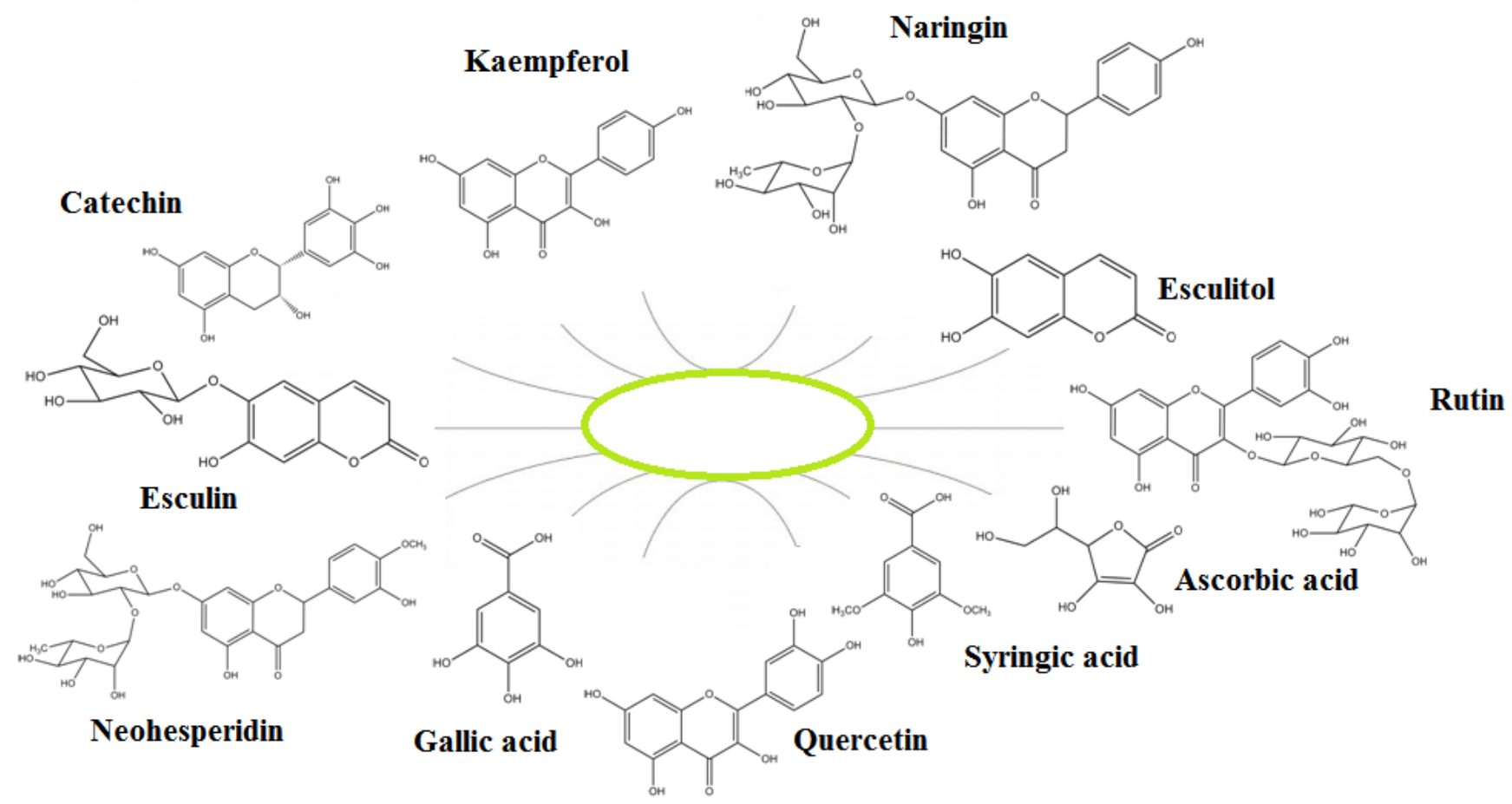

Figure 5. The main water-soluble anticorrosion and antioxidant compounds of the plant and biomass wastes extract.

In a first study J. Gust and I. Wawer explored the correlation between radical scavenging effects and anticorrosive properties of polyphenols [60]. The radical scavenging effects and anticorrosive properties of polyphenols (gallic acid [GA] and two gallotannins) that contained ortho-trihydroxyl aromatic rings but different numbers of GA moieties and different molecular masses were studied. An interdependence was shown between the rate of the scavenging effect of the polyphenols on DPPH radicals and their anticorrosive properties. It was found that the increase in the molecular mass and the orthoposition $\mathrm{OH}$ group content of the polyphenol molecules increased:

- the ability of the polyphenol to scavenge DPPH radicals;

- the degree of conversion of the rust-phase components, especially $\gamma-\mathrm{FeOOH}$;

- the degree of sealing the rust; 
- the corrosion resistance imparted to the steel by the converted rust. The authors concluded the scavenging effect of polyphenols may be used to evaluate and predict the applicability of various polyphenols to anticorrosive purposes.

The antioxidant and anticorrosive effect of Tragia involucrate L. (T. involucrate L.) were studied to help find new compounds which can be used for various purposes (Table 1). The plant belonging to Euphorbiaceae is a hispid herb, perennial plant with stinging and scattered hairs. It is found throughout in India, Burma, China and Sri Lanka. The plant is known for its biological properties such as curing skin eruptions, treating gastropathy, vomiting, inflammation, antimicrobial, antidiabetic, mosque to repellant, wound healing and antiepileptic activities [74]. The total phenolic (TPC) and flavonoid contents (TFC), antioxidant activity (DPPH, reducing potential and phosphomolybdenum), electrochemical measurements, Fourier transform infrared (FT-IR), UV-visible (UV-vis) spectral analysis, scanning electron microscopy/energy-dispersive X-ray spectroscopy (SEM-EDX) and atomic force microscopy (AFM) were done to analyse the potency and also the inhibition efficiency of $T$. involucrate $L$. against $1 \mathrm{M} \mathrm{HCl}$ on low carbon steel. These results led the authors to confirm the efficacy of $T$. involucrate $L$. in scavenging the DPPH radicals depending on concentration. The antioxidant activity of $T$. involucrate $L$. was high (92\%) at $100 \mu \mathrm{g} / \mathrm{mL}$.

The authors suggested that the radical scavenging activity of these extracts may be due to the involvement of phenolic compounds and also owing to the existence of other antioxidant secondary metabolites like flavonol, terpenoids, tannins etc. The results of reducing potential of the extracts reveal the effective reducing capacity of the extracts at all concentration points. The authors concluded that $T$. involucrate $L$. has high antioxidant capacity (487.31). The results of reducing potential and phosphomolybdenum methods are in accordance with the DPPH method. The antioxidant efficiency of polyphenols in the $T$. involucrate $L$. extracts shows the presence of phenols having B ring with $3^{\prime}, 4^{\prime}$-dihydroxy structure or heterocylic 4-oxo group conjunction with 2,3-double bond or $\mathrm{A}$ and $\mathrm{C}$ rings with 4- oxo function and 3- and 5-hydroxyl groups. The results obtained are consistent with data from other authors where according the radical scavenging ability of phenolics is due to their redox propertys which allow them to act as hydrogen donors, reducing agents and singlet oxygen quenchers. All these results showed strong evidence adding values to $T$. involucrate $L$. plant extract in inhibiting corrosion on low carbon steel and by promoting antioxidant importance of the extract which helps in scavenging free radicals.

The relationships between phenolic profiles and inhibitive actions were analyzed by comparing the trends of phenolic profiles to those of inhibition efficiency by Kang Wei Tan and M. Jain Kassim [75]. Attempts to correlate phenolic profiles with anticorrosive properties of $R$. apiculata were successful, as evident by the similarity in the $\mathrm{g} \%$ trends to the trend of CTC. Hence, there is a correlation between phenolic profiles and corrosion inhibition properties. The inhibitive properties of $R$. apiculata may be due to the presence of condensed tannin in the extracts (Table 1). 
Table 1. The plant and biomass wastes extract as corrosion inhibitors, their antioxidant/free radical scavenging activity, and nature of metal, electrolytes.

\begin{tabular}{|c|c|c|c|c|c|}
\hline \multirow[t]{2}{*}{ Plant name } & \multirow{2}{*}{$\begin{array}{l}\text { Metal and } \\
\text { electrolyte }\end{array}$} & $\begin{array}{c}\text { Antioxidant/free radical } \\
\text { scavenging activity }\end{array}$ & \multirow[t]{2}{*}{ Main constituents } & \multirow[t]{2}{*}{ Remark } & \multirow[t]{2}{*}{$\operatorname{Ref}(s)$} \\
\hline & & DPPH/ABTS & & & \\
\hline $\begin{array}{l}\text { Polyphenols (gallic acid } \\
\text { [GA] and two } \\
\text { gallotannins }\end{array}$ & - & $\mathrm{ABTS}=10-50 \%$ & & & {$[60]$} \\
\hline $\begin{array}{l}\text { Tragia involucrate L. } \\
\text { (T. involucrate L.) }\end{array}$ & Steel/1 M HCl & $\begin{array}{l}\text { DPPH }(\%)=92 \% \\
\text { at } 100 \mu \mathrm{g} / \mathrm{mL} .\end{array}$ & $\begin{array}{l}\text { Phenolic compounds: } \\
\text { flavonol, terpenoids, } \\
\text { tannins }\end{array}$ & $\begin{array}{l}\text { A maximum IE of } 88 \% \text { was } \\
\text { achieved using } 0.25 \mathrm{~g} \cdot \mathrm{L}^{-1} \text { of } \\
\text { the } T . \text { involucrate } L . \text { extract. }\end{array}$ & [74] \\
\hline R. apiculata bark & Steel/1 M HCl & & & $\begin{array}{l}\text { All mangrove bark extracts } \\
\text { were found to have some } \\
\text { degree of inhibition in } \\
\text { acidic medium. A good } \\
\text { correlation was obtained } \\
\text { between corrosion inhibition } \\
\text { properties and condensed } \\
\text { tannin contents. }\end{array}$ & [75] \\
\hline Salvia officinalis $L$ & $\begin{array}{l}\text { Steel/0.5 M } \\
\mathrm{H}_{2} \mathrm{SO}_{4}\end{array}$ & $\mathrm{IC}_{50}=309.42 \mathrm{mg} / \mathrm{ml}$ & $\begin{array}{c}\text { Polyphenols, catechics and } \\
\text { Gallic tannins, flavonoids, } \\
\text { saponins and Terpenoids. } \\
\text { Trans-Thujone }(17.74 \%), \\
\text { 1,8-cineol }(12.63 \%), \\
\text { Camphor }(12.24 \%), \\
\text { Caryophyllene }(9.87 \%), \alpha- \\
\text { pinene }(7.82 \%), \text { Dehydra- } \\
\text { Aromadendrane }(7.29 \%), \\
\text { and Guaiol }(7.03 \%) .\end{array}$ & $\begin{array}{l}\text { The latter has shown an } \\
\text { inhibition efficiency of } \\
83.06 \% \text { and } 70.58 \% \text { for the } \\
\text { both methods respectively at } \\
\text { a concentration of } 4 \mathrm{~g} / \mathrm{l} \text {, the } \\
\text { methanolic extract which } \\
\text { has shown an inhibition } \\
\text { efficiency of } 91.62 \% \text { and } \\
49.70 \% \text { respectively at the } \\
\text { same concentration. }\end{array}$ & {$[76]$} \\
\hline
\end{tabular}




\begin{tabular}{|c|c|c|c|c|c|}
\hline Plant name & $\begin{array}{l}\text { Metal and } \\
\text { electrolyte }\end{array}$ & $\begin{array}{l}\text { Antioxidant/free radical } \\
\text { scavenging activity }\end{array}$ & Main constituents & Remark & $\operatorname{Ref}(s)$ \\
\hline $\begin{array}{c}\text { Eucalyptus Globulus } \\
\text { (EG), Punica Granatum } \\
\text { (PG) and Olea } \\
\text { Europaea }(\mathrm{OE}))\end{array}$ & $\begin{array}{c}\text { Steel/ } \\
\left(0.1 \mathrm{~mol} \mathrm{~L}^{-1}\right. \\
\mathrm{NaOH}+ \\
0.5 \mathrm{~mol} \mathrm{~L}^{-1} \\
\mathrm{NaCl})\end{array}$ & $\begin{array}{c}\mathrm{EC}_{50} / \mathrm{g} \mathrm{L}^{-1}=1.83(\mathrm{EG}) ; 0.42 \\
((\mathrm{PG})) ; 5.91(\mathrm{OE})\end{array}$ & $\begin{array}{l}\text { Gallic acid, Catechin, } \\
\text { Vanillic acid, } p \text {-Coumaric } \\
\text { acid, Protocatechuic acid, } \\
\text { 4-Hydroxybenzoic acid, } \\
\text { 3,5-dimethoxy-4- } \\
\text { hydroxyacetophenone, } \\
\text { Ellagic acid, Benzoic acid }\end{array}$ & & [77] \\
\hline $\begin{array}{l}\text { Leaves of Pancratium } \\
\text { Foetidum Pom }\end{array}$ & Steel/1 M HCl & $\begin{array}{c}\text { DPPH }(\%) \text { (ether fraction })= \\
8-40 \%\end{array}$ & Polyphenols, flavonoids & $\begin{array}{l}\text { DPPH trapping activity of } \\
\text { the extracts increased in the } \\
\text { order of: diethyl ether } \\
\text { fraction < ethyl acetate } \\
\text { fraction < ascorbic acid } \\
\text { E\% of aqueous extract } \\
\text { increases from } 92.57 \% \text { to } \\
98.01 \% \text { with the increase in } \\
\text { inhibitor concentration from } \\
0.125 \text { to } 1 \mathrm{~g} / \mathrm{L} \text {. }\end{array}$ & [78] \\
\hline $\begin{array}{l}\text { Extract and essential oil } \\
\text { of Pennyroyal Mint } \\
\text { (Menthapulegium, } \\
\text { MP) }\end{array}$ & $\begin{array}{c}\text { Steel/ } \\
0.5 \mathrm{M} \mathrm{H}_{2} \mathrm{SO}_{4}\end{array}$ & $\mathrm{IC} 50=36.62 \mu \mathrm{g} / \mathrm{mL}$ & $\begin{array}{c}\text { 1,8-Cineole }(31.9 \%) \\
\text { followed by piperitone } \\
(15.6 \%), \\
\text { Limonene }(14.6 \%) \text { and } \beta \text { - } \\
\text { Pinene }(4.8 \%)\end{array}$ & $\begin{array}{l}\text { The obtained results have } \\
\text { showed that the inhibition } \\
\text { efficiency increases with } \\
\text { increasing inhibitor } \\
\text { concentration to attain } \\
90.3 \% \text { at } 2 \mathrm{~g} / \mathrm{L} \text { of MPE and } \\
87.3 \% \text { at } 4 \mathrm{~g} . \mathrm{L}^{-1} \\
\text { of MPO at } 303 \mathrm{~K}\end{array}$ & [79] \\
\hline Thymus Algeriensis & $\begin{array}{c}\text { Steel/ } \\
0.5 \mathrm{M} \mathrm{H}_{2} \mathrm{SO}_{4}\end{array}$ & $\begin{array}{c}\text { IC50 aqueous extract = } \\
32.40 \mu \mathrm{g} / \mathrm{mL}\end{array}$ & $\begin{array}{c}\text { Geranyl acetate }(80.8 \%), \\
\text { Geraniol, trans- } \\
\text { Caryophyllene }\end{array}$ & $\begin{array}{l}\text { Inhibition efficiency of the } \\
\text { Thymus algeriensis Extract } \\
\quad 95 \% \text { at } 2 \mathrm{~g} / \mathrm{L} \text {. }\end{array}$ & [80] \\
\hline
\end{tabular}




\begin{tabular}{|c|c|c|c|c|c|}
\hline Plant name & $\begin{array}{l}\text { Metal and } \\
\text { electrolyte }\end{array}$ & $\begin{array}{l}\text { Antioxidant/free radical } \\
\text { scavenging activity }\end{array}$ & Main constituents & Remark & $\operatorname{Ref}(s)$ \\
\hline $\begin{array}{l}\text { Oil palm frond lignins } \\
\text { (Elaeis guineensis) }\end{array}$ & $\begin{array}{l}\text { Mild steel/ } \\
0.5 \mathrm{M} \mathrm{HCl}\end{array}$ & $\begin{array}{c}\text { SL gives highest inhibition } \\
(\mathrm{OUI}=74 \%) \text { followed by } \\
\text { EOL }(\mathrm{OUI}=60 \%) \text { and } \mathrm{KL} \\
(\mathrm{OUI}=55 \%)\end{array}$ & & $\begin{array}{l}\text { The highest corrosion } \\
\text { inhibition efficiency for all } \\
\text { ultrafiltrated lignins were } \\
\text { attained at maximum } \\
\text { concentration of } 500 \mathrm{ppm} \\
\text { (IEP Soda: } 87 \%>\text { IEP. } \\
\text { Organosolv: } 83 \%> \\
\text { IEP.Kraft: } 81 \% \text { ). }\end{array}$ & {$[81]$} \\
\hline $\begin{array}{c}\text { Essential oil of } \\
\text { Foeniculum vulgare }\end{array}$ & $\begin{array}{c}\text { Steel/ } \\
1.0 \mathrm{M} \mathrm{HCl}\end{array}$ & & $\begin{array}{c}\text { The major constituents of } \\
\text { FVS were trans-anethole } \\
(56.86 \%) \text {, estragole } \\
(20.32 \%) \text {, and Fenchone } \\
(14.24 \%) .\end{array}$ & $\begin{array}{c}\text { The Essential oil optimum } \\
\% \text { IE of } 91.5 \% \text { at a } \\
\text { concentration of } 1.00 \mathrm{~g} / \mathrm{L} \text {. }\end{array}$ & [82] \\
\hline $\begin{array}{l}\text { The Palm oil from seed } \\
\text { of Phoenix dactylifera } \\
\text { (Oil of both Deglet } \\
\text { Nour and Kentichi) }\end{array}$ & $\begin{array}{l}\text { Mild steel/ } \\
1 \mathrm{M} \mathrm{HCl}\end{array}$ & $\begin{array}{l}\text { The DPPH scavenging } \\
\text { activity of Oil of both } \\
\text { Deglet Nour and Kentichi } \\
\text { increased in the order, } \\
\text { DegletNour Oil }(26-71 \%)< \\
\text { Kentichi Oil }(30-71 \%) \text {. }\end{array}$ & & & {$[83,84]$} \\
\hline Orange peel & $\begin{array}{l}\text { Mild steel/ } \\
0.1 \mathrm{M} \mathrm{HCl}\end{array}$ & $\begin{array}{c}\text { ABTS (TEAC/ } \mu \text { MTrolox } \\
\text { eq.) }=3.867\end{array}$ & $\begin{array}{l}\text { Neohesperidin, naringin, } \\
\text { ascorbic acid. }\end{array}$ & $\begin{array}{l}\text { The anticorrosion properties } \\
\text { of natural extracts, as } \\
\text { orange peel extract, cannot } \\
\text { be explained only by the } \\
\text { antioxidant properties of the } \\
\text { polyphenol molecules, as } \\
\text { flavonoids, contained in } \\
\text { these extracts. }\end{array}$ & {$[86]$} \\
\hline
\end{tabular}




\begin{tabular}{|c|c|c|c|c|c|}
\hline Plant name & $\begin{array}{l}\text { Metal and } \\
\text { electrolyte }\end{array}$ & $\begin{array}{l}\text { Antioxidant/free radical } \\
\text { scavenging activity }\end{array}$ & Main constituents & Remark & $\operatorname{Ref}(s)$ \\
\hline Opuntia Ficus Indica & $\begin{array}{l}\text { Mild steel/1 M } \\
\mathrm{HCl}\end{array}$ & $\mathrm{IC} 50=98 \mu \mathrm{g} / \mathrm{mL}$ & & $\begin{array}{c}\text { The inhibition efficiency } \\
(\mathrm{Ew} \%) \text { reaches a value of } \\
94 \% \text { at a concentration of } \\
\text { MFE }(1 \mathrm{~g} / \mathrm{L})\end{array}$ & [87] \\
\hline $\begin{array}{l}\text { Epipremnum aureum } \\
\quad(\text { E. aureum })\end{array}$ & $\begin{array}{l}\text { Low-carbon } \\
\text { steel (LCS) / } \\
1 \mathrm{M} \mathrm{H}_{2} \mathrm{SO}_{4}\end{array}$ & $\mathrm{DPPH}(\%)=95 \%$ & & $\begin{array}{l}\text { The maximum inhibition } \\
\text { efficiency of } 92.37 \% \text { was } \\
\text { achieved with } 600 \text { ppm of } \\
\text { E. aureum extract in } 1 \mathrm{M} \\
\mathrm{H}_{2} \mathrm{SO}_{4} \text { at } 300 \pm 1 \mathrm{~K} \text {. }\end{array}$ & {$[88]$} \\
\hline Red clover honey & $\begin{array}{l}\text { AA 2017A } \\
\text { alloy/ } \\
0.5 \text { mol L } \\
\text { NaCl solution }\end{array}$ & $\mathrm{DPPH}(\%)=23 \%$ & $\begin{array}{l}\text { Lilac aldehyde isomers } \\
\text { dominated in the } \\
\text { headspace (individual } \\
\text { range from } 7.6 \% \text { to } \\
21.4 \%) \text { followed by } \\
\text { phenylacetaldehyde } \\
(10.1-31.2 \%) \text { and } \\
\text { benzaldehyde } \\
(7.0-15.7 \%)\end{array}$ & $\begin{array}{l}\text { Maximum efficiency of } \\
76 \% \text { was achieved. }\end{array}$ & [89] \\
\hline Ammi visnaga & $\begin{array}{c}\text { Mild steel/1 M } \\
\mathrm{HCl}\end{array}$ & $\begin{array}{c}\text { DPPH, } \mathrm{IC}_{50}=2.82 \mathrm{mg} / \mathrm{mL} \\
\text { Total antioxidant capacity } \\
\text { (mg ascorbic acid/g extract), } \\
115.39 \pm 6.33 .\end{array}$ & $\begin{array}{l}\text { Flavonoids, coumarins, } \\
\text { steroids, terpenoids and } \\
\text { condensed tannins }\end{array}$ & $\begin{array}{l}\text { Inhibition efficiency of mild } \\
\text { steel rise with the increase } \\
\text { of ethanolic extract of } A m m i \\
\text { visnaga concentration up to } \\
\quad 84.82 \% \text { at } 0.3 \mathrm{~g} \mathrm{~L}^{-1} \text {. }\end{array}$ & {$[90]$} \\
\hline
\end{tabular}


Z. Khiya et al. described the chemical composition of Salvia officinalis L., collected in Khenifra region (Morocco), A phytochemical screening was done, the antioxidant activity of the extract as well as the corrosion inhibiting powers were evaluated using two methods: the potentiodynamic polarization and impedance spectroscopy (EIS) measurements [76]. The commercial importance of the Salvia officinalis L. plant is due to its richness of phenolic and volatile compounds (such as essential oils). It occupies an important place in cosmetic and food industries because of its biological properties. The authors believe that it is interesting to use these plants as a source of corrosion inhibitor. They found that the extract contained polyphenols, catechics and gallic tannins, flavonoids, saponins and terpenoids. GC-MS analysis of the Salvia officinalis L. oil has identified 105 components with the dominance of trans-Thujone (17.74\%), 1,8-cineol (12.63\%), camphor (12.24\%), Caryophyllene (9.87\%), $\alpha$-pinene (7.82\%), Dehydra-Aromadendrane $(7.29 \%)$, and Guaiol $(7.03 \%)$. However, the results show the absence of saponins, alkaloids, leucoanthocyanins and anthocyanins. All these results coincide with what was obtained by Nacéra. The results of antioxidant activity allowed the determination of IC50 $\left(\mathrm{IC}_{50}=309.42 \mathrm{mg} / \mathrm{ml}\right)$ for the oil. The anti-corrosive action of the essential oil and methanol extract of this plant reaches an efficiency of $83.78 \%$ and $91.62 \%$. The authors showed that the methanolic extract was very rich in total phenols $(1.044 \pm 0.004 \mathrm{mg} \mathrm{GAE} / \mathrm{g}$ of extract) and flavonoids ( $0.037 \pm 0.003 \mathrm{mg} \mathrm{EQ} / \mathrm{g}$ of extract).

The antioxidant and anticorrosive effect of three trees (Eucalyptus Globulus (EG), Punica Granatum (PG) and Olea Europaea $(O E)$ ) as corrosion inhibitors for steel bars in a synthetic solution that simulates the interstitial solution of concrete contaminated with chlorides were studied by N. Etteyeb and X.R. N'ovoa [77]. The authors assumed that these extracts were more effective that all tested extracts behave an important free radical scavenging activity (Table 1, Table 2). The highest activity was observed in PG trunks. These may be related to differential phenols richness in these plants. In fact, according to HPLC results, phenols were higher in PG trunks compared to EG leaves and OE rods. These results show that aqueous extracts have a strong antioxidant activity since they include gallic acid together with other phenolic acids (Figure 5). The antioxidant activity and the inhibiting property increases with increasing of the phenolic compounds content in the extract. Samples that have a high content of phenolic substances, usually have good results for antioxidant activity [77, 78]. All the plants extracts examined have a protective power and act as mixed type inhibitors for carbon steel corrosion in alkaline solution containing chlorides. The adsorption of plant extract molecules on the carbon steel surfaces leads to decreased metal-electrolyte interfacial capacitance with respect to the bare samples. P. Deepa Rani et al. [102] described the inhibition effect Punica granatum Extract on Brass in Acid Media. These authors postulated that the inhibition activities of the Punica extract is mainly attributed due to presence of the tannic acid (19\%) phenolic punicalagins, gallic acid, catechin, pectins, quercetin, rutin, flavonols, anthocyanidins. The inhibition effect of olive roots extract [103] and olive pomace extract [104] as eco-friendly 
corrosion inhibitor for steel in $\mathrm{HCl}$ medium was reported by $\mathrm{D}$. Bouknana and Driss Bouknana et al.

Table 2. Phenolic compounds in aqueous extracts of Eucalyptus Globulus, Punica Granatum and Olea Europaea.

\begin{tabular}{ccc}
\hline Eucalyptus Globulus extract & $\begin{array}{c}\text { Punica Granatum extract } \\
{[\mathbf{7 7 , 1 0 2}]}\end{array}$ & $\begin{array}{c}\text { Olea Europaea extract } \\
{[\mathbf{7 7 , 1 0 3 , 1 0 4 ]}}\end{array}$ \\
\hline Gallic acid & Gallic acid & Gallic acid \\
\hline Catechin & Catechin & Vanillic acid \\
\hline$p$-Coumaric acid & Protocatechuic acid & Protocatechuic acid \\
\hline 4-Hydroxybenzoic acid & $\begin{array}{c}\text { 3,5-dimethoxy-4- } \\
\text { hydroxyacetophenone }\end{array}$ \\
\hline & Ellagic acid & Ellagic acid \\
\hline
\end{tabular}

H. Bendaif et al. studied characteristics of polyphenols, flavonoids, antioxidant activities and inhibition property of the aqueous extract of leaves of Pancratium Foetidum Pom (LPFP) [78]. Aqueous extract of LPFP has moderate antioxidant activity. DPPH scavenging activities (\%) were increased significantly with increasing the concentration of the studied samples from 0.2 to $2 \mu \mathrm{g} / \mathrm{mL}$. Tafel polarization measurements indicate that the aqueous extract of leaves of LPFP act essentially as a mixed type inhibitor. The increase in the charge transfer resistance and decrease in double layer capacitance values, with the increase in the inhibitor concentration, showed that the aqueous extract of Pancratium Foetidum Pom formed protective layers on the mild steel surface, covering areas where $\mathrm{HCl}$ solution degrades and corrodes rapidly.

The total phenolic and flavonoid compounds present in Cryptostegia grandiflora leaf extract were analyzed by M. Prabakaran et al. [57]. The authors confirmed that the extract contains the Myricetin (3582.22 $\mu \mathrm{g} / \mathrm{g})$ and Rutin $(45.62 \mu \mathrm{g} / \mathrm{g})$ as major components that possess antioxidant and anticorrosion activity.

H. Bendaif et al. studied of antioxidant activity and inhibition of corrosion by Brazilian plant extracts such as the leaves of the species Sennacana (Nees\& Mart.) HS Irwin \& Barneby, Byrsonima sericea DC, Dimorphandra gardneriana Tul. and Mangifera Indica L. and branches of Zanthoxylum Syncarpum [59].This study reports the ability of phenolic and amino compounds contained in extracts of plants from Northeastern Brazil of inhibiting corrosion and its correlation with antiradical activity. The authors found out that the anti-radical activity is not directly related to the inhibition of corrosion, indicating that the mechanism may be associated with adsorptive surface processes.

Thus, the authors state that the sugary anticorrosive and antioxidant effect of the extractable part of the raw material is due to the presence of components of different 
polarity, both polyphenolic compounds and volatile compounds of the essential oil. It should be noted that the high antioxidant efficiency of essential oils and their main components is confirmed by a significant amount of research in the field of phytochemistry. It is only because of the traditionally established ideas and the insufficient number of studies in the correlation of anti-corrosive and antioxidant effectiveness in inhibiting the corrosion of metals that it is considered that water-soluble polyphenolic compounds make the main contribution to the mechanism of inhibition of plant extracts.

\subsection{Determination of the anticorrosion and antioxidant properties of the extract and essential oil/water-insoluble fraction}

The difference in the inhibition efficiencies of different extracts of the same plant is attributed to the presence of different constituents/phytochemicals in the extracts of different plant parts. There are several articles are available in literature in which inhibition efficiency and antioxidant properties of the essential oil and water-insoluble fraction have been evaluated as corrosion inhibitors. The antioxidant and anticorrosive properties of different oils obtained from plants were investigated by different authors [79-80]. Thus, A. Salhi et al. studied the chemical composition of essential oil and antioxidant and anticorrosion activity of extract and essential oil of Pennyroyal Mint (Menthapulegium, MP). GC-MS analysis of essential oil isolated from M. pulegium (PMO) plant shows that its composition is dominated by 1,8 -Cineole, piperitone, Limonene and $\beta$-Pinene $(31.9 \%$, $15.6 \%, 14.6 \%$ and $4.8 \%$, respectively). These authors observed that poly-phenolic extract has moderate free radical scavenging activity. The inhibition efficiency of MPE and MPO increases with an increase in inhibitor concentration and decreases with the rise in temperature. MPE and MPO act as mixed-type inhibitors without modifying the mechanism of hydrogen evolution. The adsorption of inhibitors on mild steel surface in $\mathrm{H}_{2} \mathrm{SO}_{4}$ solution follows Langmuir isotherm for both inhibitors MPE and MPO.

During the separate studies, the same authors investigated the antioxidant activity and the inhibitive action of T. algeriensis oil (TAO) and its extract (TAE) on corrosion behavior of carbon steel in $0.5 \mathrm{M} \mathrm{H}_{2} \mathrm{SO}_{4}$ using weight loss, potentiodynamic polarization and electrochemical impedance spectroscopy (EIS) methods [80]. The essential oil was characterized by high amounts of Geranyl acetate (80.8\%). The other major components were Geraniol $(7.3 \%)$ and trans-Caryophyllene $(2.4 \%)$. Results of the antioxidant activity performed by DPPH have shown that the aqueous extract possess a moderate reducing power by comparing with the positive controls. Those results can be attributed to the existence of polyphenols compounds in the aqueous extract. The polarization studies showed that TAO and TAE inhibit both cathodic hydrogen reduction reactions and anodic metal dissolution, and then they act as mixed-type inhibitors of corrosion.

M. Hazwan Hussin et al. studied the antioxidant properties of lignins extracted from oil palm biomass using Kraft, soda, and organosolv pulping [81]. The potential of the extracted lignins as inhibitors of mild steel corrosion was also assessed. They concluded that soda-extracted lignins displayed the highest antioxidant activities as compared to Kraft 
and ethanol organosolv lignins. The highest inhibition of corrosion of mild steel was reached in the presence of soda-extracted lignins. Oil palm fronds are potential sources of lignins usable as green antioxidant for corrosion inhibition of mild steel (IE $=81 \%$ ). Potentiodynamic polarization measurements demonstrate that ultrafiltrated lignins act as mixed-type inhibitors with predominant anodic (organosolv lignin) or cathodic (alkaline lignin) effectiveness.

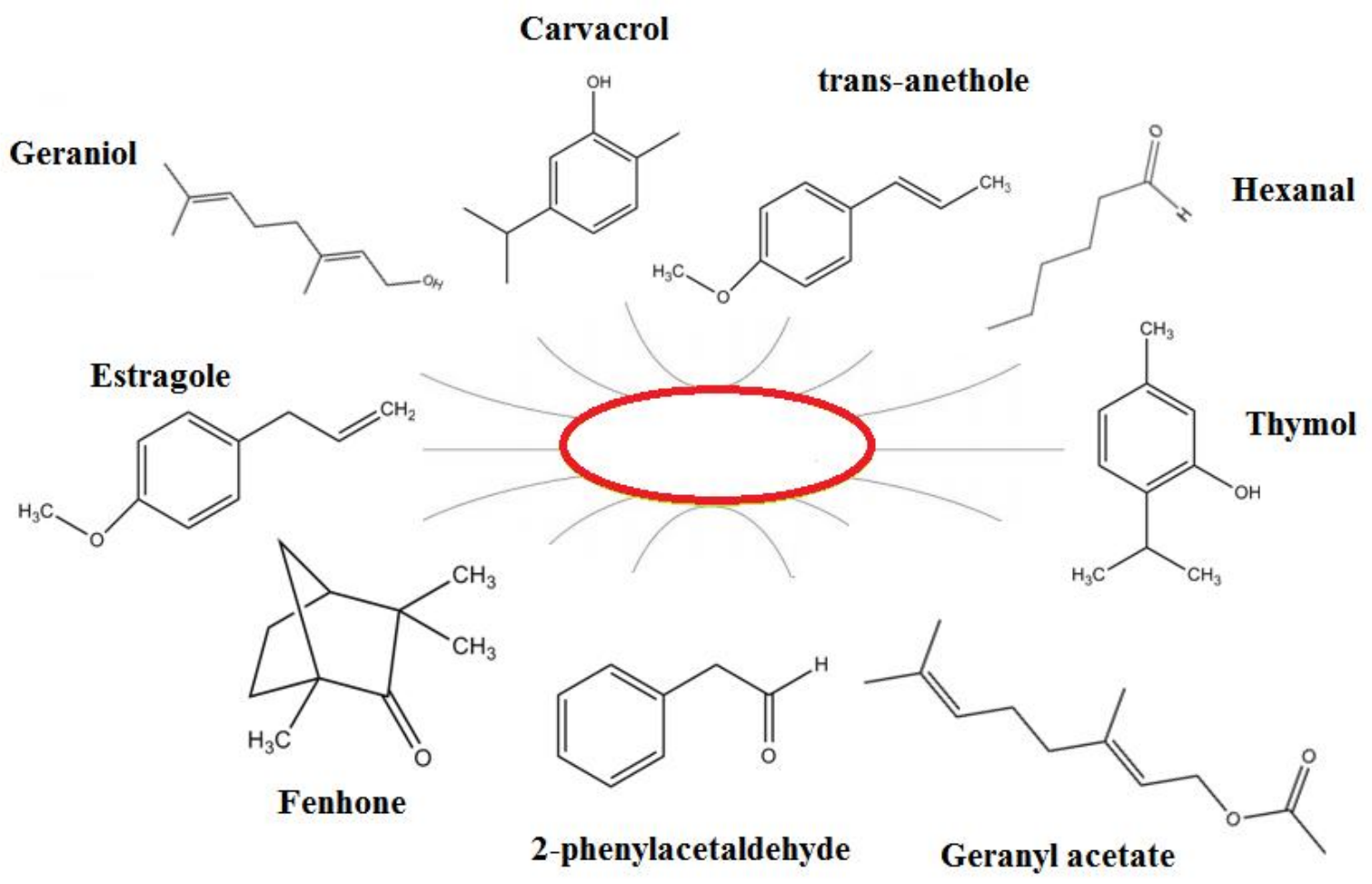

Figure 6. The main water-insoluble anticorrosion and antioxidant fractions of the plant/essential oil and biomass wastes extract.

Some reports are available on the effect of the oil extracted from the seeds of Foeniculum vulgare which is tested as a corrosion inhibitor for mild steel in $\mathrm{HCl}$ solution [82]. The authors using several methods for evaluation of the inhibition efficiency including weight loss measurements, potentiodynamic polarization, electrochemical impedance spectroscopy technique and scanning electron microscopy to better visualize the topography of the corroded metal surface. It was found that major constituents of FVS were trans-anethole (56.86\%), estragole (20.32\%), and Fenchone (14.24\%). FVS acts as an excellent inhibitor without modifying the hydrogen reduction mechanism; its inhibition efficiency increases with increased inhibitor concentration to reach a maximum value of $94 \%$ with a concentration of $1.0 \mathrm{~g} / \mathrm{L}$ in $1.0 \mathrm{M} \mathrm{HCl}$ solution.

Y. El Ouadi et al. had proven the corrosion inhibition and antioxidants potential of the palm oil from seed of Phoenix dactylifera (Oil of both Deglet Nour and Kentichi) [83]. This manuscript concluded that the Palm oil seed can reduce the radical 2,2-diphenyl-1picrylhydrazyl, so they have an antioxidant effect in vitro, and can be proposed as new 
potential sources of natural corrosion inhibitor. The GC-MS analysis of the palm oils shows that its composition is dominated by fatty acid (Lauric, Myristic, Palmitic, 9Octadecenoic and 8,11-Octadecadienoicacids). Further, Tafel polarization measurements indicate that the two varieties of Palm oil act essentially as a mixed type inhibitors. Results obtained through weight loss measurements and electrochemical tests demonstrated that the two varieties of Palm oil act as efficient corrosion inhibitors of the mild steel in $1 \mathrm{M}$ $\mathrm{HCl}$ solution.

The antioxidant activity of essential oils of different species of the genus Satureja has been the subject of several studies [84,85]. Ozturk has highlighted an important antioxidant activity of Satureja. Inhibition of carbon steel corrosion by a carvacrol film forming on the metal surface was studied by a volatile inhibiting ability test and electrochemical measurement. Morphology of the film on the carbon steel surface was investigated by SEM, (FT-IR) measurement [98]. R. Sh. Kuliev et al. described the antioxidant and anticorrosion properties of vegetable oils [105].

The antioxidant power of Satureja Cuneifolia essential oil was also explained by the high content in Carvacrol. It has been reported that essential oils of the genus Satureja are rich in isopropanoids such as Thymol, Carvacrol, $\beta$-caryophyllene, $\gamma$-Terpinene, $p$-cymene and Linalool which are known for their antioxidant properties. Antioxidants play a role in the capture of free radicals and a role to stabilize a radical by the transfer of a hydrogen atom. The antioxidant activity of essential oils is, therefore, in close collaboration with the chemical structure of its components.

Recently, however, in the study of the anti-corrosion properties of plant extracts, more and more attention is paid to the component composition and antioxidant properties of model substances.

N. M'hiri et al. reported the corrosion inhibition of carbon steel in acidic medium by orange peel extract and its main antioxidant compounds [86]. The inhibiting effect on acidic steel corrosion brought by the extract and selected antioxidant compounds (neohesperidin, naringin, ascorbic acid) was evaluated separately by electrochemical methods. Stationary electrochemical measurements show that the decrease of the corrosion rate of steel is due to an inhibition of both cathodic reaction of $\mathrm{H}^{+}$reduction and anodic reaction of iron oxidation. As mentioned by several studies on natural extracts, the cathodic inhibition can mainly be explained by the antioxidant properties of flavonoids contained in these extracts. The authors showed that the orange peel extract presents higher antioxidant activity than expected by adding individual contributions of the major phenolic compounds (neohesperidin, hesperidin, nobiletin, naringin, narirutin) and ascorbic acid. Two reasons can explain this result: some natural antioxidants such as carotenoids (not taken into account in this study) can be partially responsible for the over-all antioxidant activity of the extract, or some synergistic effects can be observed between different antioxidant molecules, particularly between flavonoids and ascorbic acid, as already noted by some authors. The authors have established that as shown by the ABTS test, the antioxidant activity of the main compounds identified in the orange peel extract depends on the 
molecule structure. Whereas hesperidin, neohesperidin and ascorbic acid show similar antioxidant activities, narirutin and naringinareare about ten times less efficient. Indeed, the antioxidant activity of these molecules is explained by the presence of enediol group for ascorbic acid, and the vicinity of $-\mathrm{OCH}_{3}$ and $-\mathrm{OH}$ groups in the $\mathrm{B}$ ring for neohesperidin (and hesperidin). These two kinds of organic functions have a radical scavenging activity comparable to the one observed in presence of a catechol group. In contrast, narirutin and naringin only contain one $-\mathrm{OH}$ group in the $\mathrm{B}$ ring; consequently their activity is much lower.

The authors claim that the anticorrosion properties of natural extracts, as orange peel extract, cannot be explained only by the antioxidant properties of the polyphenol molecules, as flavonoids, contained in these extracts [86]. As shown in this study, the presence of enediol or catechol functions or other derived functions are responsible for antioxidant activity of molecules and could partly explain the inhibition of cathodic reaction. The same kinds of functions could also be responsible for the anodic inhibition because of their chelating properties regarding metallic cations. However, the significant inhibition efficiency obtained with the extract is also due to the precipitation of a covering film on steel surface, which could be formed by other macromolecules acting in synergy with the antioxidant molecules.

This flavonoid can be found in many fruits (especially the citrus fruits orange, grapefruit, lemon, and lime) or apple, peaches, and cereal such as buckwheat seeds. Esculin and esculetol belong to the family of coumarin. Particularly, esculin is a coumarin glucoside that naturally occurs in some trees or seeds (horse chestnut for example). Esculetol is the same molecule as esculin without the glucoside group. These three molecules present three different configurations of the catechol group. It was found thatradical scavenging properties of antioxidant molecules induce cathodic inhibition. Radical scavenging properties of antioxidant molecules induce cathodic inhibition. While the growth of a conversion film of catecholate complex provides an anodic inhibition. From a corrosion point of view, the free-radical scavenging properties of these molecules induce a decrease of the oxygen reduction kinetic, similar with film-forming molecules (rutin, esculetol) and a non-forming one (esculin).

Antioxidant and anti-corrosion activities of the methanolic extract of Opuntia Ficus Indica flowers from Morocco were investigated by N. Saidi et al. [87]. As a result of their study, it was found that the methanol extract display significant antiradical activity, with IC50 value of $98 \mu \mathrm{g} / \mathrm{mL}$. The antioxidant activity detected for the methanol extract from O. ficusindica flowers could be attributed to the hydrogen donating effect of phenolic compounds and flavonoids. Results obtained through weight loss measurements and electrochemical tests demonstrated that methanolic flowers extract was an efficient ecofriendly green corrosion inhibitor for mild steel in $1 \mathrm{M} \mathrm{HCl}$ solution.

Some the authors evaluated the antioxidant and inhibitory potential of E. aureum on the corrosion of low-carbon steel (LCS) in $1 \mathrm{M} \mathrm{H}_{2} \mathrm{SO}_{4}$ using antioxidant assays, surface and non-electrochemical studies [88]. Epipremnum Aureum (EA) extract was found to be an 
effective antioxidant due to the presence of phenols and flavonoids, making it eligible for use in the pharmaceutical, medical, and chemical industries. The correlation of all the antioxidant assays can be taken as strong evidence for the potent antioxidant activity of the phenols and flavonoids of E. aureum. The extract of EA in $\mathrm{MeOH}(100 \%)$ was found to efficiently inhibit the corrosion of LCS in $1 \mathrm{M} \mathrm{H}_{2} \mathrm{SO}_{4}$. Mass loss analysis demonstrated that $[\eta(\%)]$ increased with increasing concentration of the extract, but decreased with temperature. The maximum $[\eta(\%)]$ of the E. aureum extract in $1 \mathrm{M} \mathrm{H}_{2} \mathrm{SO}_{4}$ for the

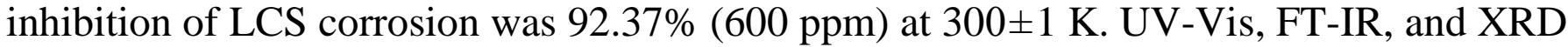
analyses revealed that $E$. aureum effectively protected the metal via the formation of a protective film. The results obtained from AAS analysis were in good agreement with the mass loss method.

I. Jerkovic' et al. evaluated the volatiles chemical-profiling and antioxidant and anticorrosion capacity of honey from the red clover (Trifolium Pratense L.). Higher aliphatic alcohols and hydrocarbons were the predominant constituents of the honey extracts [89]. The honey and its extracts exhibited rather weak anti-radical activity (DPPH assay) and total antioxidant activity (FRAP assay). On the other hand, the honey's inhibitive properties towards the corrosion of AA 2017A alloy in $\mathrm{NaCl}$ solution (potentiodynamic polarisation and potentiostatic pulse measurements) revealed the honey to be a very good anodic inhibitor (efficiency up to 76\%) while the honey extracts (USE) showed better inhibition efficacy.

S. Aourabi et al. described the anticorrosion and antioxidant activities of ethanolic extract of Ammi visnaga [90]. They concluded that ethanolic extract of Ammi visnaga consists of flavonoids, coumarins, steroids, terpenoids and condensed tannins. The antioxidant activity of ethanolic extract of Ammi visnaga, evaluated by DPPH and total antioxidant capacity methods, show significantly high values $\left(\mathrm{IC}_{50}=2.82 \mathrm{mg} / \mathrm{mL}\right)$. Quantitative analysis shows that this extract is rich in polyphenols particularly condensed tannins and flavonoids, which are responsible for the antioxidant activity. Besides, the ethanolic extract of Ammi visnaga ensures the inhibition of mild steel corrosion in $1 \mathrm{M}$ $\mathrm{HCl}$ medium by formation of a protective film. The polarization study shows that the ethanolic extract of Ammi visnaga acts as a mixed type inhibitor, while the electrochemical impedance spectroscopy results show that as the inhibitor concentration is increased, the charge transfers resistance rise and the double layer capacity decreases. The inhibition efficiency follows the same trend from the three understand gravimetric, potentiodynamic polarization (Tafel) and electrochemical impedance spectroscopy methods. The adsorption of ethanolic extract of Ammi visnaga obeys the Langmuir isotherm model.

The antioxidant and anticorrosive properties of crude glycerol fraction from biodiesel production was studded by M. Jerzykiewicz et al. [92]. 1,2,3-Propanetriol-containing fractions exhibited high free radical scavenging properties, in comparison with biodiesel and oil material. Additionally, the Herbert test proved the anticorrosive ability of the crude glycerol fractions investigated. Radical scavenging (antioxidant) properties obtained from 
EPR spectroscopy paralleled the anticorrosive investigations, with samples having the highest quenching abilities giving the best results in the Herbert tests.

In the literature, there are also materials on the study of antioxidant and anti-corrosion ability of synthesized corrosion inhibitors [96,97,99] and hydrophobic antioxidant polymers [93]. Thus ten derivatives of (2Z,4E)-3-hydroxy-1-(2-hydroxyphenyl)-5phenylpenta-2,4-dien-1-one were investigated for their antioxidant properties and corrosion inhibition potentials [93]. The compounds were screened for their antioxidant activity using the 2,2-diphenyl-1-pycrylhydrazyl (DPPH) radical scavenging assay and the ferric reducing antioxidant power (FRAP) assay. The compounds were also tested for possible anticorrosion properties using the potentiodynamic polarization and electrochemical impedance spectroscopy techniques. All the compounds showed appreciable corrosion inhibition efficiency for mild steel in $1 \mathrm{M} \mathrm{HCl}$. These compounds are mixed-type inhibitors. The adsorption of the compounds on a mild steel surface obeyed the Temkin adsorption isotherm and the derived adsorption thermodynamic parameters indicate a spontaneous and chemical adsorption process.

H. Hlushko et al. described synthetic polymeric antioxidants as powerful inhibitors of corrosion of metals $[94,95]$. Hydrophobic synthetic antioxidant copolymers, containing catechol or gallol moieties, can be used as single layer individual coatings or as additives to epoxy-based coatings for protection of AA2024 substrates. These coatings are largely transparent and thus enable visual inspection of underlying substrates for signs of emerging corrosion. The unique combination of polyphenol and hydrophobic functionalities within synthetic polymer molecules enable engineering of robust, non-leachable epoxy coatings, which retain high resistance to corrosion in highly corrosive $0.6 \mathrm{M} \mathrm{NaCl}$ solutions for at least 100 days.

On the basis of ongoing discussion it can be concluded that plants/agro-food wastes extracts are green and sustainable inhibitors for corrosion of metals and alloys [96-100].

H.M. Hassan et al. synthesized and tested of some new antioxidant and anticorrosion additives (heterocycles) with potential for use in turbine aviation oils, gasoline motor oils [106-108]. Some the authors evaluated of some new oxazolones and imidazolones as antioxidant additives for Egyptian lubricating oils [109].

P.A. Sørensen et al. described antioxidants (i.e., free radical scavengers and peroxide decomposers) have been incorporated into various generic types of coatings to investigate the effect of antioxidants on the rate of cathodic delamination of epoxy coatings on coldrolled steel [110]. Testing using substrates prepared from stainless steel, copper, aluminum, galvanized steel, and brass also showed a reduction in the rate of cathodic delamination when the coating was modified with a free radical scavenger. The protective mechanism of free radical scavengers investigated for the primers are similar to that of antioxidants used for protection against photochemical degradation by UV-radiation of top coatings. Both substrate corrosion and degradation of a coating exposed to UV-radiation lead to the formation of free radicals as reactive intermediates. 


\section{Conclusions}

From the ongoing discussion it can be concluded that plant extracts are ideal candidates to replace traditional expensive and toxic inorganic and synthetic organic corrosion inhibitors. The great number of works dealing with natural compounds as corrosion inhibitors, on the other side, did not pay any kind of attention to aspect of antioxidant capacity and correlations between them. The plant extracts contain several phytochemicals/constituents that can easily adsorb and inhibit metallic corrosion. The anticorrosion properties of the plants/agro-food wastes extract cannot be explained only by the antioxidant properties. However, the correlation dependence of the increase in the degree of corrosion protection with an increase in total antioxidant capacity or antioxidant/free radical scavenging activity of the extracts is observed. The total antioxidant activity of the plants/agro-food wastes extracts is the result of individual activities of each of the antioxidant compounds (watersoluble fraction and a water-insoluble fraction) present such as tocopherols, carotenoids, and phenolic compounds, the latter being the major phytochemicals responsible for antioxidant activity of plant materials. Moreover, these compounds render their effects via different mechanisms such as radical scavenging, metal chelation, quenching of singlet oxygen and so on to act as antioxidants and anticorrosion agent. It can be concluded that antioxidative capacity testing has become an important tool in the search for anticorrosion substances, and for raw material selection and evaluation they inhibition properties as well.

\section{References}

1. B. Wu, J.-L. Cao and L. Kang, J. Constr. Steel Res., 2017, 135, 150-161. doi: 10.1016/j.jcsr.2017.04.020

2. S.H. Zaferani, M. Sharifi, D. Zaarei and M.R. Shishesaz, J. Environ. Chem. Eng., 2013, 1, no. 4, 652-657. doi: 10.1016/j.jece.2013.09.019

3. C. Verma, E.E. Ebenso and M. Quraishi, J. Mol. Liq., 2017, 233, 403-414. doi: 10.1016/j.molliq.2017.02.111

4. C. Verma, E.E. Ebenso and M. Quraishi, J. Mol. Liq., 2017, 248, 927-942. doi: 10.1016/j.molliq.2017.10.094

5. S.H. Zaferani, M. Sharifi, D. Zaarei and M.R. Shishesaz, J. Environ. Chem. Eng., 2013, 1, no. 4, 652-657. doi: 10.1016/j.jece.2013.09.019

6. M. Panayotova, Y. Garbatov and C.G. Soares, Corrosion of steels in marine environment, monitoring and standards, Safety and reliability of industrial products, systems and structures, Ed. C.G. Soares, London, UK, Taylor \& Francis Group, 2008, 369.

7. M.G. Fontana, Corrosion engineering, Tata McGraw-Hill Education, 2005.

8. J.R. Davis, Surface engineering for corrosion and wear resistance, ASM International, 2001.

9. R.W. Revie, Corrosion and corrosion control, John Wiley \& Sons, 2008. 
10. A. Isenberg, Energy conversion via solid oxide electrolyte electrochemical cells at high temperatures, Solid State Ionics, 1981, 3, 431.

11. D. Landolt, Corrosion and surface chemistry of metals, CRC Press, 2007.

12. C. Luo, X. Zhou, G. Thompson and A. Hughes, Corros. Sci., 2012, 61, 35-44. doi: 10.1016/j.corsci.2012.04.005

13. Yu.I. Kuznetsov, Russ. Chem. Rev., 2004, 73, no. 1, 75-87. doi: $10.1070 /$ RC2004v073 n01ABEH000864

14. N.N. Andreev and Yu.I. Kuznetsov, Russ. Chem. Rev., 2005, 74, no. 8, 685-695. doi: 10.1070/RC2005v074n08ABEH001162

15. Yu.I. Kuznetsov and L.P. Kazansky, Russ. Chem. Rev., 2008, 77, no. 3, 219. doi: 10.1070/RC2008v077n03ABEH003753

16. Yu.I. Kuznetsov, Int. J. Corros. Scale Inhib., 2015, 4, no. 4, 284-310. doi: 10.17675/2305-6894-2015-4-4-1

17. Yu.I. Kuznetsov, Int. J. Corros. Scale Inhib., 2016, 5, no. 4, 282-318. doi: 10.17675/2305-6894-2016-5-4-1

18. Yu.I. Kuznetsov, Int. J. Corros. Scale Inhib., 2017, 6, no. 3, 209-239. doi: 10.17675/2305-6894-2017-6-3-1

19. Yu.I. Kuznetsov, Int. J. Corros. Scale Inhib., 2017, 6, no. 4, 384-427. doi: 10.17675/2305-6894-2017-6-4-3

20. R.A. Sheldon, Metrics of Green Chemistry and Sustainability: Past, Present, and Future. ACS Sustain, Chem. Eng., 2018, 6, 32.

21. P.T. Anastas and M.M. Kirchhoff, Acc. Chem. Res., 2002, 35, 686.

22. M. Chigondo and F. Chigondo, Recent Natural Corrosion Inhibitors for Mild Steel: An Overview, J. Chem., 2016, 1. doi: 10.1155/2016/6208937

23. P.B. Raja and M.G. Sethuraman, Mater. Lett., 2008, $62,113$.

24. N.A. Odewunmi, S.A. Umoren and Z.M. Gasem, J. Environ. Chem. Eng., 2015, 3, 286.

25. T. Overchenko, S. Frolenkova and V. Vorobyova, J. Chem. Technol. Metall., 2019, 54, no. 1,72 .

26. M. Ramezanzadeh, Z. Sanaeia, G. Bahlakeh and B. Ramezanzadeh, J. Mol. Liq., 2018, 256, 67-83. doi: 10.1016/j.molliq.2018.02.021

27. T. Benabbouha, M. Siniti, H. El Attari, K. Chefira, F. Chibi, R. Nmila and H. Rchid, J. Bio Tribo Corros., 2018, 4, 39. doi: 10.1007/s40735-018-0161-0

28. A.S. Fouda, G.Y. El-Awady and W.T. El Behairy, J. Bio Tribo Corros., 2018, 4, 8.

29. L.A. Corrêa Matos, M.C. Taborda, G.J. Turcatel Alves, M.T. da Cunha, E. do P. Banczek, M.F. Oliveira, E. D'Elia and P.R. Pinto Rodrigues, Int. J. Electrochem. Sci., 2018, 13, 1577. doi: 10.20964/2018.02.01

30. K. Nasr, M. Fedel, K. Essalah, F. Deflorian and N. Souissi, Anti-Corros. Meth. Mater., 2018, 65, 292. doi: 10.1108/ACMM-12-2017-1869

31. P.E. Alvarez, M.V. Fiori-Bimbi, A. Neske, S.A. Brandán and C.A. Gervasi, J. Ind. Eng. Chem., 2018, 58, 92-99. doi: 10.1016/j.jiec.2017.09.012 
32. E. Alibakhshi, M. Ramezanzadeh, G. Bahlakeh, B. Ramezanzadeh, M. Mahdavian and M. Motamedi, J. Mol. Liq., 2018, 255, 185. doi: 10.1016/j.molliq.2018.01.144

33. C. Verma, M.A. Quraishi, E.E. Ebenso and I. Bahadur, J. Bio Tribo Corros., 2018, 4, 33. doi: $10.1007 / \mathrm{s} 40735-018-0150-3$

34. Y. Qiang, S. Zhang, B. Tan and S. Chen, Corros. Sci., 2018, 133, 6-16. doi: 10.1016/j.corsci.2018.01.008

35. F. El-Taib Heakal, M.A. Deyab, M.M. Osman and A.E. Elkholy, Desalination, 2018, 425, 111-122. doi: 10.1016/j.desal.2017.10.019

36. R.S. Al-Moghrabi, A.M. Abdel-Gaber and H.T. Rahal, Int. J. Ind. Chem., 2018, 9, 255-263. doi: 10.1007/s40090-018-0154-3

37. T.K. Bhuvaneswari, V.S. Vasantha and C. Jeyaprabha, Silicon, 2018, 10, 1793-1807. doi: $10.1007 / \mathrm{s} 12633-017-9673-3$

38. A. Saxena, D. Prasad, R. Haldhar, G. Singh and A. Kumar, J. Environ. Chem. Eng., 2018, 6, 694-700. doi: 10.1016/j.jece.2017.12.064

39. P. Parthipan, P. Elumalai, J. Narenkumar, L.L. Machuca, K. Murugan, O.P. Karthikeyan and A. Rajasekar, Int. Biodeterior. Biodegrad., 2018, 132, 66-73. doi: 10.1016/j.ibiod.2018.05.005

40. X. Jiang, C. Lai, Z. Xiang, Y. Yang, B. Tan, Z. Long, L. Liu, Y. Gu, W. Yang and X. Chen, Int. J. Electrochem. Sci., 2018, 13, 3224-3234. doi: 10.20964/2018.04.16

41. A.H. Al-Moubaraki, Anti-Corros. Meth. Mater., 2018, 65, no. 1, 53-65. doi: https://doi.org/10.1108/ACMM-04-2017-1788

42. D.K. Verma, F. Khan, I. Bahadur, M. Salman, M.A. Quraishi, C. Verma and E.E. Ebenso, Results Phys., 2018, 10, 665-674. doi: 10.1016/j.rinp.2018.06.003

43. N. Raghavendra and J.I. Bhat, Chem. Eng. Commun., 2018, 205, no. 2, 145-160. doi: 10.1080/00986445.2017.1370709

44. M. Srivastava, P. Tiwari, S.K. Srivastava, A. Kumar, G. Ji and R. Prakash, J. Mol. Liq., 2018, 254, 357-368. doi: 10.1016/j.molliq.2018.01.137

45. V. Vorobyova, O. Chygyrynets', M. Skiba, T. Zhuk, I. Kurmakova and O. Bondar, Int. J. Corros. Scale Inhib., 2018, 7, no. 2, 185-202. doi: 10.17675/2305-6894-2018-7-2-6

46. V. Vorobyova, M. Skiba and Olena Chygyrynets', Pigm. Resin Technol., 2018. doi: https://doi.org/10.1108/PRT-03-2018-0025

47. V. Vorobyova, O. Chygyrynets', M. Skiba, I. Trus and S. Frolenkova, Chem. Chem. Technol., 2018, 12, no. 3, 410. doi: 10.23939/chcht12.03.410

48. A.S. Fouda, H.M. El-Abbasy and A.A. El-Sherbini, Int. J. Corros. Scale Inhib., 2018, 7, no. 2, 213-235. doi: 10.17675/2305-6894-2018-7-2-8

49. F. Krid, E. Zouaoui and M.S. Medjram, Chem. Chem. Technol., 2018, 12, no. 3, 405. doi: $10.23939 /$ chcht12.03.405

50. E. Chygyrynets' and V. Vorobyova, Chem. Chem. Technol., 2014, 8, 235.

51. V. Vorob'iova, O. Chyhyrynets' and O. Vasyl'kevych, Mater. Sci., 2015, 50, no. 5, 726-735. doi: $10.1007 / \mathrm{s} 11003-015-9778-\mathrm{Z}$ 
52. O.E. Chyhyrynets' and V.I. Vorob'iova, Mater. Sci., 2013, 49, no. 3, 318-325. doi: 10.1007/s11003-013-9617-z

53. O.E. Chyhyrynets, Y.F. Fateev, V.I. Vorobiova and M.I. Skyba, Mater Sci., 2016, 51, no. 5, 644-651. doi: 10.1007/s11003-016-9886-4

54. V. Vorobyova, O. Chygyrynets', M. Skiba, I. Kurmakova and O. Bondar, Int. J. Corros. Scale Inhib., 2017, 6, no. 4, 485-503. doi: 10.17675/2305-6894-2017-6-4-8

55. S. Marzorati, L. Verotta and S. Trasatti, Molecules, 2019, 24, no. 1, 48. doi: 10.3390/molecules24010048

56. Y. Zou, Y. Lu and D. Wei, J. Agric. Food Chem., 2004, 52, no. 16, 5032-5039. doi: $\underline{10.1021 / \mathrm{jf0} 049571 \mathrm{r}}$

57. M. Prabakaran, S.-H. Kim, V. Hemapriya and I.-M. Chung, J. Ind. Eng. Chem., 2016. doi: $10.1016 /$ j.jiec.2016.03.006

58. R.A. Sheldon, Green chemistry and resource efficiency: towards a green economy, Green Chemistry, 2016, 18, no. 11, 3180-3183. doi: 10.1039/C6GC90040B

59. J.M. Ferreira Jr., M.G. de Vasconcelos Silva, J.A. Monteiro, B.A. de Sousa, M.J.C. Falcão and de Morais, S.M., Int. J. Electrochem. Sci., 2016, 11, 3862.

60. J. Gust and I. Wawer, Corrosion, 1995, 51, no. 1, 37. doi: 10.5006/1.3293574

61. S.M.M. Shanab, M.A. Ameer, A.M. Fekry, A.A. Ghoneim and E.A. Shalaby, Int. J. Electrochem. Sci., 2011, 6, 3017.

62. L.F. Montoya, D. Contreras, A.F. Jaramillo, C. Carrasco, K. Fernándezd, B. Schwederskie, D. Rojasb and M.F. Melendrez, Prog. Org. Coat., 2019, 127, 100109. doi: $10.1016 /$ j.porgcoat.2018.11.010

63. J.J. Gracenea, J.J. Saura and J.J. Suay, Prog. Org. Coat., 2004, 50, no. 1, 68-74. doi: 10.1016/j.porgcoat.2003.10.014

64. M.R. Mahmoudian, Y. Alias, W.J. Basirun and M. Ebadi, Appl. Surf. Sci., 2013, 268, 302-311. doi: 10.1016/j.apsusc.2012.12.082

65. P. Sadighara, S. Gharibi, A.M. Jafari, G.J. Khaniki and S. Salari, Avicenna J. Phytomed, 2012, 2, 113.

66. D. Krishnaiah, R. Sarbatly and R. Nithyanandam, Food Bioprod. Process., 2011, 89, no. 3, 217-233. doi: 10.1016/j.fbp.2010.04.008

67. A. Munir, B. Sultana, A. Bashir, A. Ghaffar, B. Munir, G. Abbas Shar, A. Nazir and M. Iqbal, Pol. J. Environ. Stud., 2018, 27, no. 2, 947-952. doi: 10.15244/pjoes/69944

68. D. Huang, B. Ou, and R.L. Prior, J. Agric. Food Chem., 2005, 53, no. 6, 1841-1856. doi: $10.1021 / \mathrm{jf030723 \textrm {c }}$

69. D. Atmani, N. Chaher, M. Berboucha, K. Ayouni, H. Lounis, H. Boudaoud, N. Debbache and D. Atmani, Food Chem., 2009, 112, no. 2, 303-309. doi: 10.1016/j.foodchem.2008.05.077

70. C.H. Okino Delgado and L.F. Fleuri, Food Rev. Int., 2015, 32, no. 1, 1-14. doi: $\underline{10.1080 / 87559129.2015 .1041183}$

71. P.M. Pilar and M.A. Pineda, Anal. Biochem., 1999, 269, no. 2, 337-341. doi: $\underline{10.1006 / a b i o .1999 .4019}$ 
72. R. Re, N. Pelligrini, A. Proteggente, A. Pannala, M. Yang and C.A. Rice-Evans, Free Radical Biol. Med., 1999, 26, no. 9-10, 1231-1237. doi: $\underline{10.1016 / \text { S0891- }}$ 5849(98)00315-3

73. D.T. Maheshwari, M.S. Yogendra Kumar, S.K. Verma, V.K. Singh and S.N. Singh, Food Chem. Toxicol., 2011, 49, no. 9, 2422-2428. doi: 10.1016/j.fct.2011.06.061

74. I. Chung, S. Kim, V. Hemapriya, K. Kalaiselvi and M. Prabakaran, Chin. J. Chem. Eng., 2018 (In Press). doi: 10.1016/j.cjche.2018.10.008

75. K.W. Tan and M.J. Kassim, Corros. Sci., 2011, 53, 569.

76. Z. Khiya, M. Hayani, A. Gamar, S. Kharchouf, S. Amine, F. Berrekhis, A. Bouzoubae, T. Zair and F. Elhilali, J. King Saud Univ., Sci., 2018 (In Press). doi: 10.1016/j.jksus.2018.11.008

77. N. Etteyeb and X.R. Nóvo, Corros. Sci., 2016, 112, 471-482. doi: 10.1016/j.corsci.2016.07.016

78. H. Bendaif, A. Melhaoui, A. Bouyanzer, B. Hammouti and Y. El Ouadi, J. Mater. Environ. Sci., 2017, 8, no. 12, 4475.

79. A. Salhi, A. Bouyanzer, A. Chetouani, S. El Barkany, H. Amhamdi, I. Hamdani, A. Zarrouk, B. Hammouti, J.M. Desjobert and J. Costa, Mor. J. Chem. 2017, 5, no. 1, $59-71$.

80. A. Salhi, A. Bouyanzer, I. El Mounsi, H. Bendaha, I. Hamdani, E. El Ouariachi, A. Chetouani, N. Chahboun, B. Hammouti, J.M. Desjobert and J. Costa, J. Mater. Environ. Sci., 2016, 7, no. 11, 3949.

81. M.H. Hussin, A.M. Shah, A.A. Rahim, M.N.M. Ibrahim, D. Perrin and N. Brosse, Ann. For. Sci., 2015, 72, no.1, 17-26. doi: 10.1007/s13595-014-0405-1

82. A. Bouoidina, M. Chaouch, A. Abdellaoui, A. Lahkimi, B. Hammouti, F. El-Hajjaji, M. Taleb and A. Nahle, Anti-Corros. Meth. Mater., 2017, 64, no. 5, 563-672. doi: 10.1108/ACMM-10-2016-1716

83. Y. El Ouadi, A. Beladjila, A. Bouyanzer, Z. Kabouche, H. Bendaif, F. Youssfi, M. Berrabah, R. Touzani, A. Chetouani and B. Hammouti, Mor. J. Chem., 2017, 5, 1139.

84. S. Bagheri, H. Ahmadvand, A. Khosrowbeygi, F. Ghazanfari, N. Jafari, H. Nazem and R.H. Hosseini, Asian Pac. J. Trop. Biomed., 2013, 3, no. 1, 22-27. doi: 10.1016/S22211691(13)60018-0

85. D. Bukvički, D. Stojković, M. Soković, L. Vannini, C. Montanari, B. Pejin and P.D. Marin, Meat Sci., 2014, 96, no. 3, 1355-1360. doi: 10.1016/j.meatsci.2013.11.024

86. N. M'hiri, D. Veys-Renaux, E. Rocca, I. Ioannou, N.M. Boudhrioua and M. Ghoul, Corros. Sci., 2016, 102, 55-62. doi: 10.1016/j.corsci.2015.09.017

87. N. Saidi, H. Elmsellem, M. Ramdani, F. Yousfi, R. Rmili, K. Azzaoui, A. Aouniti and N. Chahboun, J. Mater. Environ. Sci., 2016, 7, no. 11, 4105.

88. M. Prabakaran, V. Hemapriya, S.-H. Kim and I.-M. Chung, Arab. J. Sci. Eng., 2018. doi: $10.1007 / \mathrm{s} 13369-018-3398-5$ 
89. I. Jerković, A. Radonić, M. Kranjac, M. Zekić, Z. Marijanović, S. Gudićc and M. Kliškić, Chem. Pap., 2016, 70, no. 6, 726-736. doi: https://doi.org/10.1515/chempap2016-0016

90. S. Aourabi, M. Driouch, K. Ammor, M. Sfaira, M.E. Touhami and F. Mahjoubi, Anal. Bioanal. Electrochem., 2018, 10, no. 7, 912.

91. M. Jerzykiewicz, I. Cwielaga and W. Jerzykiewicz, J Chem Technol Biotechnol., 2009, 84, 1196.doi:https://doi.org/10.1002/jctb.2157

92. M.I.K. Momin, I. Bahadur, E.E. Ebenso, M.S. Islam, L.O. Olasunkanmi, D. Ramjugernath and N.A. Koorbanally, J. Mol. Liq., 2016, 223, 819. doi: 10.1016/j.molliq.2016.08.107

93. H. Hlushko, Y. Cubides, R. Hlushko, T.M. Kelly, H. Castaneda and S.A. Sukhishvili, ACS Sustainable Chem. Eng., 2018, 6, no. 11, 14302-14313. doi: 10.1021/acssuschemeng.8b02966

94. F.A. Ansari, C. Verma, Y.S. Siddiqui, E.E. Ebenso and M.A. Quraishi, Int. J. Corros. Scale Inhib., 2018, 7, no. 2, 126-150. doi: 10.17675/2305-6894-2018-7-2-2

95. I.M. Kurmakova, O.S. Bondar, N.R. Demchenko, V.I. Vorobyova and O.Y. Kupchyk, Int. J. Corros. Scale Inhib., 2018, 7, no. 3, 308-317. doi: 10.17675/2305-6894-2018-73-2

96. I.M. Kurmakova, O.S. Bondar, V.I. Vorobyova, M.I. Skiba, S.V. Tkachenko and O.P. Makey, Int. J. Corros. Scale Inhib., 2018, 7, no. 4, 582-592. doi: 10.17675/23056894-2018-7-4-7

97. V. Vorobyova, O. Chygyrynets', M. Skiba, I. Kurmakova and O. Bondar, Int. J. Corros. Scale Inhib., 2017, 6, no. 4, 485-503. doi: 10.17675/2305-6894-2017-6-4-8

98. I. Kurmakova, N. Demchenko, O. Bondar and V. Vorobyova, Chem. Chem. Technol., 2018, 12, no. 4, 519-522. doi: 10.23939/chcht12.04.519

99. O. Bondar, V. Vorobyova, I. Kurmakova and O. Chygyrynets, Chem. Chem. Technol., 2018, 12, no. 1, 127-133. doi: 10.23939/chcht12.01.127

100. V. Vorobyova, O. Chygyrynets and M. Skiba, J. Chem. Technol. Metall., 2018, 53, no. 2, 336-345.

101. D. Veys-Renaux, S. Reguer, L. Bellot-Gurlet, F. Mirambet and E. Rocca, Corros. Sci., 2018, 136, 1-8. doi: $10.1016 /$ j.corsci.2018.02.015

102. P. Deepa Rani and S. Selvaraj, J. Phytol., 2010, 2, no. 11, 58-64. http://updatepublishing.com/journal/index.php/jp/article/view/2195

103. D. Bouknana, B. Hammouti, H. Serghini caid, S. Jodeh, A. Bouyanzer, A. Aouniti and I. Warad, Int. J. Ind. Chem., 2015, 6, no. 4, 233-245. 10.1007/s40090-015-0042-Z

104. D. Bouknana, B. Hammouti, M. Messali, A. Aounitia and M. Sbaa, Asian Pac. J. Trop. Dis., 2014, 4, no. 2, 963-974. doi: 10.1016/S2222-1808(14)60767-2

105. R.S. Kuliev, F.A. Kuliev, A.A. Mutalibova and S.R. Kulieva, Chem. Technol. Fuels. Oils, 2006, 42, no. 1, 55-59. doi: 10.1007/s10553-006-0029-8

106. H.M. Hassan, M.M. Youssif, A.M. Khalil and E.H.E. Youssif, Lubr. Sci., 2000, 17, no. 1, 55-69. doi: $\underline{10.1002 / j s l .3000170107}$ 
107. H.M. Hassan, O.M.O. Habib, E.B. Moawad, G.G. El-Bana and A.M. El Defrawy, Lubr. Sci., 2011, 23, no. 3, 119-138. doi: $\underline{10.1002 / \mathrm{ls} .146}$

108. O.M.O. Habib, H.M. Hassan, E.B. Moawad and M. El-Hadidy, Pet. Sci. Technol., 2010, 28, no. 10, 1059-1067. doi: 10.1080/10916460902967742

109. A. El-Mekabaty, O.M.O. Habib, Hassan, H.M. and E.B. Moawad, Pet. Sci., 2012, 9, no. 3, 389-399. doi: $10.1007 / \mathrm{s} 12182-012-0223-8$

110. P.A. Sørensen, C.E. Weinell, K. Dam-Johansen and S. Kiil., J. Coat. Technol. Res., 2010, 7, no. 6, 773-786. doi: 10.1007/s11998-010-9267-0 